\title{
Post-COVID-19 SME financing constraints and the credit guarantee scheme solution in Spain
}

\author{
Félix Corredera-Catalán ${ }^{1} \cdot$ Filippo di Pietro $^{2} \cdot$ Antonio Trujillo-Ponce $^{3}$ (1)
}

Accepted: 16 February 2021 / Published online: 9 March 2021

(c) The Author(s), under exclusive licence to Springer Nature Limited 2021

\begin{abstract}
Countries around the world are working hard to fight against the economic crisis caused by the coronavirus pandemic, with a special emphasis on small- and medium-sized enterprises (SMEs) due to their vulnerability and importance in the business ecosystem. This paper analyzes the Spanish guarantee model and the measures taken by regional governments in conjunction with the main mutual guarantee societies (MGSs) to mitigate the economic problems associated with the COVID-19 pandemic. We show that public administrations may use guarantee schemes as instruments to improve SME access to financing while limiting the burden on the public budget.
\end{abstract}

Keywords COVID-19 $\cdot$ SMEs $\cdot$ Credit risk $\cdot$ Mutual guarantee societies $\cdot$ Bank financing

\section{Introduction}

The coronavirus pandemic is the largest public health crisis in living memory, which has also led to an unprecedented economic crisis on a global scale [1]. Although the impacts of the pandemic affect both larger and smaller firms, the effect on small- and medium-sized enterprises (SMEs) is especially severe, particularly because of the higher levels of vulnerability and lower resilience related to the size of these firms. ${ }^{1}$ In this line of research, recent works provide evidence of how SMEs have been hit harder by the crisis than larger firms [2-5]. This impact may particularly be felt in specific sectors such as tourism, but also among SMEs catering to local markets where containment measures have been introduced [1]. ${ }^{2}$

SMEs are the backbone of the European Union (EU) economy; they represented approximately $99.8 \%$ of all nonfinancial business enterprises in 2018, accounted for $66.6 \%$ of total employment and generated $56.4 \%$ of the value added

Antonio Trujillo-Ponce

atrujillo@upo.es

1 International Doctoral School, Universidad de Sevilla, 41013 Seville, Spain

2 Department of Financial Economics and Operations Management, Universidad de Sevilla, 41018 Seville, Spain

3 Department of Financial Economics and Accounting, Universidad Pablo de Olavide, 41013 Seville, Spain in that area [6]. Almost all the EU SMEs (93\%) are classified as "micro" enterprises, with 'accommodation and food services,' 'business services,' 'construction,' and 'retail and wholesale trade' being the most important sectors in terms of creating employment. ${ }^{3}$

Access to financing is one of the most critical environmental conditions for SMEs as well as for entrepreneurs [7, 8]; SMEs experience many difficulties in obtaining funding for new investment projects, particularly in their early stages. Credit conditions heavily affect the decision-making process of companies without much of a track record or size [9],

\footnotetext{
1 We follow the EU definition of SME, according to which these are defined as enterprises that employ fewer than 250 persons and either have an annual turnover that does not exceed 50 million euros, or an annual balance sheet not exceeding 43 million. Moreover, an enterprise is any entity engaged in an economic activity, irrespective of its legal form. In practice, this means that the self-employed that are regularly engaged in an economic activity are included in this definition.

2 The COVID-19 pandemic was first confirmed to have spread to Spain on January 31, 2020, when a German tourist tested positive for SARS-CoV-2 in La Gomera, Canary Islands. Eight pieces of legislation-Royal Decree-Law 6/2020, Royal Decree-Law 7/2020, Royal Decree 463/2020, Royal Decree-Law 8/2020, Royal Decree 465/2020, Royal Decree-Law 9/2020, Royal Decree-Law 10/2020 and Royal Decree-Law 11/2020 — provided initial measures to address the COVID-19 crisis. These measures were at the national level, and they have been supplemented by measures at the regional and local levels. The legislation includes measures that address health and the economy at large, with an emphasis on SMEs.

${ }^{3}$ Micro-enterprises are defined as firms that employ fewer than 10 persons and whose annual turnover or annual balance sheet total does not exceed 2 million euros.
} 
especially in some European countries where bank funding is the most relevant source of financing for SMEs and equity and debt securities are much less frequently considered [10-12].

The literature reports that the financial difficulties of SMEs are a consequence of different factors: high dependence on one or a few people (low capital diversification) [13], low levels of capitalization (more sensitive to market volatility) [13], a lack of clarity in asset ownership between assets privately owned and those owned by the business [13], incomplete or unclear financial statements [14, 15], insufficient management capacity [16-18], and banks' preference for larger business customers, which are considered more lucrative and less risky [13].

These financial restrictions are revealed in many ways: (i) in the quantity, where SMEs receive fewer funds than requested [19]; (ii) in the price, where financing becomes more expensive due to the increased interest-rate, given the risk associated with the loan [19-21]; (iii) in the loan term, where the SME obtains credit with shorter repayment periods than expected $[22,23]$; and (iv) in the guarantees, where the financial entities tighten access to credit conditions through bank guarantee requirements or other kinds of additional guarantees [19, 24]. In fact, SMEs point out that one of the most important problems in their financing is that they are unable to provide the collateral requested by the lender [25]. This request is, in many cases, the result of an insufficient analysis of the company, and the collateral acts as an instrument to mitigate the information asymmetries without increasing the assessment costs [26].

All of these difficulties have led policymakers to focus on policies and institutions that help alleviate SMEs' financing problems, with credit guaranteeing being a commonly used risk transfer tool to overcome these constraints [27]. The credit guarantee scheme implies that the guarantee institution will reimburse the bank a predetermined percentage of the outstanding loan in the case of the SME's default. In other words, by reducing (or even eliminating) the financial loss suffered by the lender, credit guarantee schemes can mitigate information asymmetries between banks and SMEs, improving their access to funds and/or reducing their costs.

This paper shows that public administrations may use guarantee schemes as instruments to improve SMEs' access to financing while limiting the burden on public budgets. Directed credit programs and credit subsidies with the aim of alleviating SMEs' financing constraints have rarely had the success they expected due to mistargeting, rent-seeking and lack of fiscal sustainability [28]. ${ }^{4}$ In fact, banks consider

\footnotetext{
${ }^{4}$ However, given the exceptional and unprecedented nature of the situation caused by the coronavirus pandemic, in some European countries there is currently an intense debate about the need to offer direct, non refundable, subsidies to the companies most affected by the consequences of the COVID-19 crisis.
}

guarantee schemes to be the most common and effective public administration programs for SME financing [29]. Guarantee schemes might also play an important role during financial crises because they provide a higher degree of confidence in the financial system [28]. Arping et al. [30] conclude that support funds should be channeled first to credit guarantee schemes and then, when entrepreneurs start to substitute public for private collateral, to co-funding entrepreneurial projects.

After this introduction, the remainder of this paper is structured as follows. The next section discusses the credit guarantee schemes designed in the EU to reduce SME financing problems. "The Spanish guarantee system" section analyzes the mutual guarantee model operating in Spain. The "MGSs as a tool for the economic management of the COVID-19 pandemic" section examines the measures taken by regional governments in conjunction with the main Spanish guarantee companies to mitigate the economic problems associated with the coronavirus pandemic. The "Concluding remarks" section concludes.

\section{EU credit guarantee schemes}

Given the difficulty that SMEs have in accessing funding, European authorities work to improve the financing environment for these businesses, and the role of guarantee systems in this task has been recognized for a long time. In September 1991, the EU Commission report concluded that "despite many initiatives in all Member States and at the Community level, representations from SMEs and independent research points to the continuing problems experienced by SMEs in obtaining access to finance and with regard to its cost. One of the most effective ways of assisting SMEs in overcoming these difficulties has been found to be the mutual guarantee system, which is a market-oriented response by SMEs to the problems they face." 5

As stated in the "Introduction" section, SMEs are typically limited in their capacity to access credit because of under-collateralization, limited credit history, and, often, a lack of expertise needed to produce sophisticated financial statements [27]. By providing a (partial or total) guarantee of the loan, the guarantor can help the SME compensate for the lack of collateral or creditworthiness; thus, the guarantee

\footnotetext{
5 "The role of mutual guarantee systems in the financing of SMEs in the European Community", Communication from the Commission, SEC (91) 1550 final, 5 September 1991 [EU Commission-SEC Document].
} 
constitutes an interesting tool to improve SME access to bank financing. Specifically, a credit guarantee scheme is a risk transfer and risk diversification tool, as the issuer of the guarantee assumes repayment of part (or all) of the loan upon firm default [28]. ${ }^{6}$ Moreover, it is often remarked that a loan guarantee scheme will help the small business market avoid the adverse information problem that leads to credit rationing in Stiglitz and Weiss' [32] model [31]. ${ }^{7,8}$

The presence of guarantee schemes in EU initiatives for SME financing has increased due to the 2007/2008 economic crisis, and more recently because of the coronavirus pandemic. EU financing programs are generally channeled through financial intermediaries, which are closer to SMEs and are well qualified to judge their needs. In this vein, through the Loan Guarantee Facility (LGF), the European Commission program for the Competitiveness of Enterprises and Small and Medium-sized Enterprises (COSME) funds guarantees and counter-guarantees to selected financial intermediaries (e.g., guarantee institutions, banks, leasing companies). In fact, under the COSME program, whose financial instruments are managed by the European Investment Fund (EIF), the European Commission incentivizes financial intermediaries to provide better financing

\footnotetext{
${ }^{6}$ Guarantee schemes can help diversify risk across lenders with different sectoral or geographic specialization [28]. In fact, Honohan [31] states this reason as one of the main causes for the development of credit guarantee systems.
}

7 As stated by OECD [33], credit rationing is said to occur if (i) among loan applicants who appear to be identical, some receive credit while others do not; or (ii) there are identifiable groups in the population that are unable to obtain credit at any price.

${ }^{8}$ SMEs are particularly affected by the credit rationing argument because the problem of information asymmetry is more acute in their case. This often leads to situations in which lending is not based on expected return but rather upon access to collateral, which may reduce or eliminate contract problems such as "moral hazard" and "adverse selection", and provides equity-type funding limiting the downside loss for the lender [27, 34].

9 The European Commission also has other programs to help SMEs access financing: the InnovFin Programme (Horizon 2020), which provides loans and guarantees to innovative businesses, finances research and development projects and provides equity-type funding (early and start-up phase); the Creative Europe program, for loans to SMEs in the cultural and creative sectors; the program for Employment and Social Innovation (EaSI), which offers microloans up to 25,000 euros to microenterprises and to vulnerable persons who wish to set up or develop a microcompany; the European Structural and Investment Funds (ESI funds), which provides loans, guarantees, equity financing and business grants; and the business loans, microfinance, guarantees and venture capital offered by either the European Investment Bank or the EIF.

${ }^{10}$ In the context of the COVID-19 pandemic, as part of an overall package of measures agreed to by the Eurogroup and the European Council, the European Investment Bank (EIB) Group (i.e., the EIB and the EIF) has established a Pan-European Guarantee Fund (the "EGF") with a targeted size of 25 billion euros. Under this EGF, the EIF has deployed a number of guarantee products in cooperation with selected financial intermediaries, with a particular focus on SMEs and small mid-caps. conditions to SMEs hit by the economic impact of the pandemic [35]..$^{9,10}$

The importance of this instrument for policymakers is reflected in the fact that all EU member states make use of these guarantee systems (in many cases supported by one or more of the EU programs described above). However, guarantee schemes vary in practice due to the different economic and historical backgrounds and legal contexts that exist in EU countries [13]. We can distinguish two general models according to the legal personality of the entity issuing the guarantee: guarantee societies versus guarantee programs [36]. ${ }^{11}$

Guarantee societies operate under a private legal framework as a commercial society or a regulated institution. These societies are the result of a social agreement among shareholders who permanently supply private and/or public capital and participate in the management of the entities. When resources mainly come from the business sector, they are called mutual guarantee societies (MGS); in corporate guarantee societies (CGS), resources predominantly come from the public and financial sectors. ${ }^{12}$ In the first case, entrepreneurs and SMEs have an active role, direct or indirect (e.g., through business associations), in management, whereas in the second case, the public sector and financial entities take on this active position. Guarantee societies usually examine the eligibility of firms, assess credit risk on an individual basis and decide whether the guarantee will be granted. ${ }^{13,14}$ They also assume nonpayment and insolvency and directly manage default recovery activities. As the detailed information the guarantee institution has about their members is transferred to the bank, the relationship between borrowers and lenders can be improved to the extent that it represents an ex-ante positive signal to the bank about the creditworthiness of the firm [27]. This can favor the development of a longer-term trust-based relationship, also reducing the incidence of information asymmetries between SMEs and banks [31]. Their consideration as a financial entity in

\footnotetext{
11 There are countries where the different models coexist in a synchronous way.

12 MGSs are also known as mutual guarantee associations, mutual guarantee institutions, or mutual guarantee companies.

13 This kind of retail-type guarantee is more common among mutual schemes [27]. It is often said that MGSs can carry out a more indepth analysis of the SME's creditworthiness, based on a better understanding of their member activities.

${ }^{14}$ In some cases, credit risk analysis is done by both the guarantee society and the bank [27].
} 
Table 1 Types of credit guarantee schemes in the EU-27. Source: Pombo et al. [36]

\begin{tabular}{ll}
\hline Type of credit guarantee scheme & EU countries \\
\hline System based on mutual guarantee societies (MGSs) & Austria \\
& Belgium \\
France \\
Germany \\
System based on corporate guarantee societies (CGSs) & Hungary \\
& Italy \\
& Luxembourg \\
& Portugal \\
Guarantee program managed by public administration bodies (ministerial departments or & Spain \\
institutions delegated) & Sweden \\
& Austria \\
Guarantee program managed by a specialized public institution & Belgium \\
& France \\
& Greece \\
& Hungary \\
& Lithuania \\
& Poland \\
& Romania \\
& Austria \\
& Belgium \\
Bulgaria
\end{tabular}

some systems has important consequences for the company, as it implies they are controlled by the national supervisor and thus ensures an optimum certification and weighting of guarantees in the context of the Basel Capital Accords [37]. Their activity can be local, regional, or national.

Guarantee programs are usually managed by a public institution specializing in the promotion of SMEs (public agency, public financial institution, etc.) or directly by a public administration body (e.g., a ministerial department). These entities provide limited resources to the system according to the rules established by the program (generally through a guarantee fund), but their direct involvement in management, credit risk assessment, and loss recovery is less common [27]. There are two main ways of managing coverage in these guarantee programs: either through an expected loss mechanism, or through direct coverage by the guarantor of a percentage of the total operation.

Table 1 shows the EU countries that use one or more of the guarantee schemes analyzed above.

\footnotetext{
15 The Spanish Government has also set up important guarantee programs managed through the Spanish Official Credit Institute (Instituto de Crédito Oficial-ICO), a state-owned bank, to deal with the eco-
}

\section{The Spanish guarantee system}

Spain has adopted a scheme based mainly on nonprofit MGSs, which develop their activity under a private legal framework as financial entities and are supervised by the Bank of Spain. ${ }^{15}$ There are currently 18 MGSs (they are so-called Sociedades de Garantía Recíproca), 17 regional companies (one for each Spanish region), and one national and sectorial entity (working for the audiovisual sector).

The first movement for a credit guarantee system in Spain started in the 1970s at the request of different business circles as a possible solution to the economic crisis, an environment characterized by high interest and a high default rate, that made it extremely difficult for SMEs to

\footnotetext{
Footnote 15 (continued)

nomic impact of COVID-19. For SMEs, the guarantee covers up to $80 \%$ of the loan value. As of December 31, 2020, 944,588 operations were guaranteed by the ICO, for a total guaranteed amount of 87,086 million euros (of which $74 \%$ correspond to SMEs). This has enabled the mobilization of 114,648 million euros.
} 


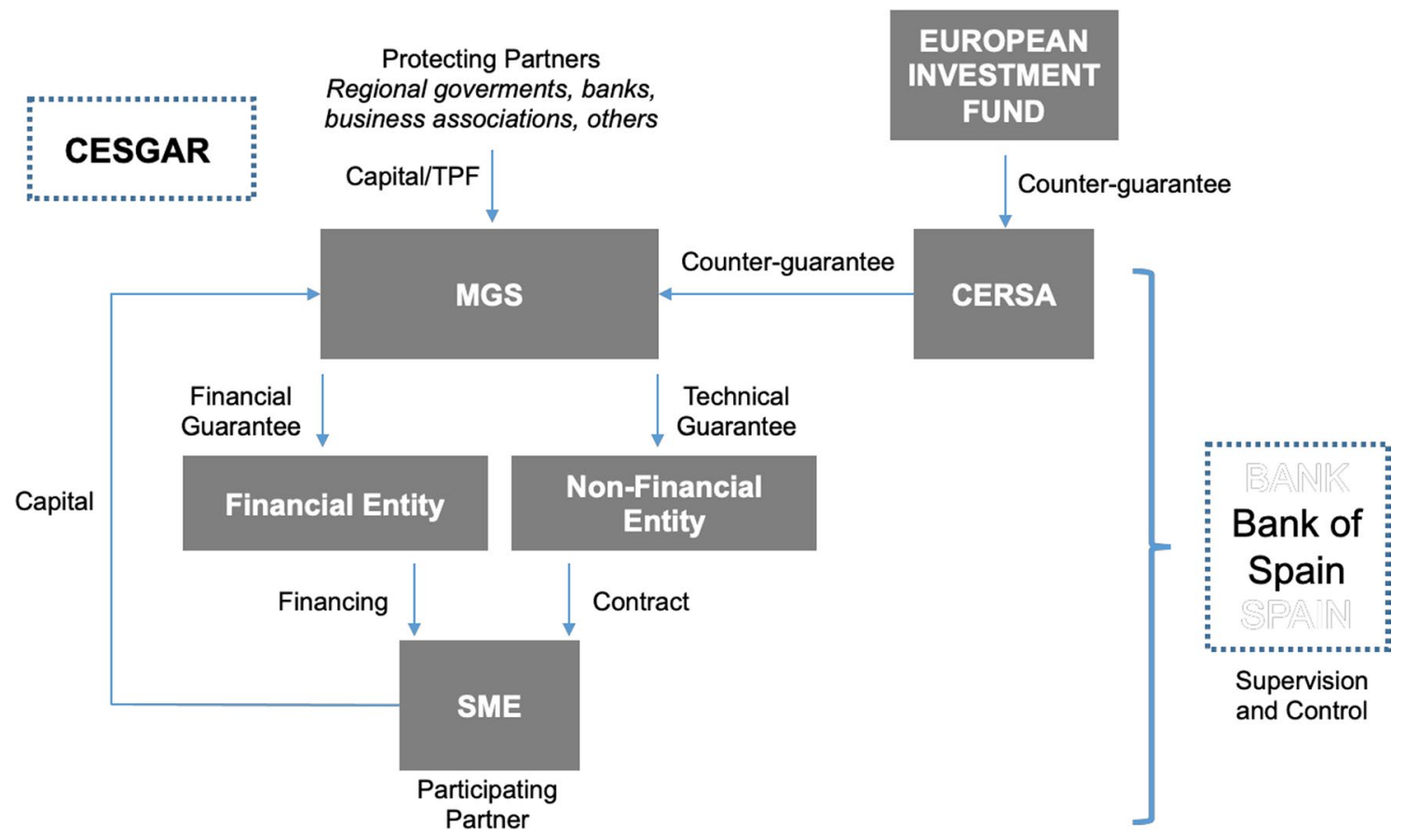

Fig. 1 The credit guarantee scheme in Spain

access financing. Royal Decree 1885/1978 attempted to implement the French model's mutualistic character by creating participating (SMEs, beneficiaries of the guarantees) and protecting (larger private and public entities) partners. MGS solvency was mainly the result of the participating partners' contributions, either to capital (funds recovered by the SME once the operation was completed) or to the guarantee fund (including accrued interest and subtracting the default cases). The number of MGSs grew significantly (over thirty entities) due to the low requirements to set up an MGS (a 300,000 euro minimum contribution and 10 founding participating partners) and to the absence of any supervisory authority.

In the following years, there were many additional regulations as a consequence of the limitations of Royal Decree $1885 / 1978$, causing the legislation to be extremely detailed. In 1988, the Discipline and Credit Institutions Intervention Act (Law 26/1988) implemented an important change as the Central Bank of Spain became the MGS supervisory institution instead of the Ministry of Economy. Later, the adoption of Law 1/1994 consolidated the regulations and introduced relevant improvements to the system, such as considering MGSs to be financial entities (therefore, a part of the legislation on credit institutions applies to them), allowing MGSs to provide financial advisory services, either directly or indirectly, substituting the initial "guarantee fund" with a "technical provisions fund (TPF)" which is considered equity and can include subsidies, donations, or other nonrefundable contributions from both public and private institutions (i.e., protecting partners now have a more relevant role in the solvency of the society), and creating a public counter-guarantee system (a public company that guarantees a part of the operations guaranteed by the MGS, i.e., a double-guarantee system). ${ }^{16}$

In recent years, the Spanish government has published two significant laws affecting MGS activity. Law 14/2013 increased the own-funds requirements regulated by Law $1 / 1994$, requiring at least 10 million euros of capital (before that, 1.8 million euros) and raising the minimum amount for own resources to 15 million euros. These higher requirements prompted some mergers in the sector [36]. Law $5 / 2015$ mainly affected the corporate governance of MGSs by stating that MGSs should comply with the criteria and control procedures and the reputation, experience, and good government requirements generally established for credit institutions [37]. ${ }^{17,18}$

Figure 1 summarizes the current functioning of the credit guarantee scheme in Spain.

\footnotetext{
${ }^{16}$ Law 1/1994, dated 11 March, on the legal regime for mutual guarantee societies (published in the Spanish official bulletin of March 12).

${ }^{17}$ Law 14/2013, dated 27 September, on support to entrepreneurs and their internationalization (published in the Spanish official bulletin of September 28).

${ }^{18}$ Law 5/2015, dated 27 April, on promoting business finance (published in the Spanish official bulletin of April 28).
} 
Table 2 Evolution of the main variables of the Spanish mutual guarantee system (2015-2019). Source: CESGAR [25]

\begin{tabular}{llllr}
\hline Year & $\begin{array}{l}\text { Number of pro- } \\
\text { tecting partners }\end{array}$ & $\begin{array}{l}\text { Number of participating } \\
\text { partners (SMEs) }\end{array}$ & $\begin{array}{l}\text { Formalized guarantees (in } \\
\text { thousands of euros) }\end{array}$ & $\begin{array}{l}\text { Outstanding risk (in } \\
\text { thousands of euros) }\end{array}$ \\
\hline 2019 & 799 & 134,618 & $1,415,629$ & $4,319,547$ \\
2018 & 799 & 130,478 & $1,282,246$ & $4,149,576$ \\
2017 & 800 & 126,591 & $1,183,755$ & $4,031,854$ \\
2016 & 792 & 122,198 & $1,097,354$ & $4,005,405$ \\
2015 & 800 & 118,879 & 974,407 & $4,073,568$ \\
\hline
\end{tabular}

As previously stated, Spanish MGSs include both participating and protecting partners. The participating partners, SME beneficiaries of the guarantees, contribute to the equity of society with funds that are used as collateral to back loans granted to the members themselves. Once the loan is fully repaid, they can recover their participation (approximately $1.5 \%$ of the loan amount). ${ }^{19}$ The protecting partners (public administrations, chambers of commerce, business associations, credit institutions, etc.) improve the solvency of the MGS by providing nonreimbursable funds to society (either through capital or the TPF). Banks appreciate MGS activity because they obtain a qualified, up to $100 \%$, guarantee of the loan that allows them to avoid provisions and reduce capital requirements [38]. Moreover, as is pointed out in the "EU credit guarantee schemes" section, because the cost of default is eliminated (transferred to the MGS), risk analysis and monitoring costs are consequently reduced. In addition to this type of (financial) guarantee, MGSs give technical guarantees. They respond to the breach of the commitments that the SME has contracted, generally with a public administration. Technical guarantees facilitate SME access to public tendering.

MGSs are associated with the Spanish MGS Confederation (CESGAR), which assumes the coordination, cooperation, defense, and representation of its associates while promoting all kinds of agreements with public and private institutions. Furthermore, the Spanish system of public support to MGSs is based mainly on counter-guarantees granted by CERSA (Compañía Española de Reafianzamiento, S.A.), an instrumental company of the central government that receives significant support from EU programs. The coverage rate (up to $80 \%$ ) depends on policy priorities, such as innovation promotion, and types of operations, such as investments or working capital needs [38]. The public counter-guarantee considerably reduces the risk that the bank assumes with the loan guaranteed by the MGS, which should

\footnotetext{
19 In addition, SMEs must pay some non recoverable costs: (i) The underwriting and origination fee, that is charged only once, when the operation is approved; and (ii) The guarantee fee, which is usually charged as a percentage of the amount due each year.
}

translate into improved credit conditions for the SME. The Bank of Spain supervises both the MGSs and CERSA.

Tables 2, 3 and 4 show the most significant data of the activity of the Spanish MGSs in 2019 as well as the evolution of the most representative variables during the period 2015-2019. Table 2 reports that the number of beneficiary SMEs (participating partners) and the amount of formalized guarantees increased by approximately 13 and $45 \%$, respectively, from 2015 to 2019 . The number of protecting partners remained practically unchanged during this period, while the outstanding risk increased by $6 \%$. If we analyze the distribution of this outstanding risk (see Table 3), we find that the services sector is the main beneficiary of the guarantees, followed at a considerable distance by the industrial and commercial sectors. Regarding the destination of the guarantees, the data show that guarantees are mainly used for investment projects, followed by working capital financing operations. A characteristic that distinguishes MGSs is that they mainly finance long-term business projects (more than $60 \%$ of operations have a term greater than 8 years). Furthermore, Table 3 shows that companies with fewer than 50 workers are the main beneficiaries of the guarantees, representing $86 \%$ of the outstanding risk. Finally, Table 4 reports data on the five most important Spanish MGSs according to outstanding risk in 2019.

\section{MGSs as a tool for the economic management of the COVID-19 pandemic}

The Spanish constitutional system establishes a system of recognition of territorial autonomy that legally and administratively materializes in deep decentralization. Territorially, the decentralization system consists of 17 regional public administrations with a broad spectrum of political and financial autonomy (Autonomous Communities). As regional governments are the majority partners (as protecting members) in the capital of MGSs, they have chosen these societies as one of the main financial instruments to fight against COVID-19 economic effects in SMEs. MGSs have also received additional support from CERSA, the instrumental company of the Spanish central government, which approved a special line of credit for SMEs affected by the 
Table 3 Outstanding risk distribution of the Spanish mutual guarantee system (as of December 31, 2019). Source: CESGAR [25]

\begin{tabular}{|c|c|c|}
\hline Outstanding risk & $\begin{array}{l}\text { Number of guar- } \\
\text { antees (in \% of } \\
\text { total) }\end{array}$ & $\begin{array}{l}\text { Amount in thousands } \\
\text { of euros (in \% of } \\
\text { total) }\end{array}$ \\
\hline \multicolumn{3}{|l|}{ By Sector } \\
\hline Primary & $\begin{array}{l}3,971 \\
(5 \%)\end{array}$ & $\begin{array}{l}290,449 \\
(7 \%)\end{array}$ \\
\hline Industry & $\begin{array}{l}11,827 \\
(15 \%)\end{array}$ & $\begin{array}{l}869,363 \\
(20 \%)\end{array}$ \\
\hline Construction & $\begin{array}{l}12,711 \\
(17 \%)\end{array}$ & $\begin{array}{l}412,180 \\
(10 \%)\end{array}$ \\
\hline Service & $\begin{array}{l}34,955 \\
(46 \%)\end{array}$ & $\begin{array}{l}1,939,321 \\
(45 \%)\end{array}$ \\
\hline Commerce & $\begin{array}{l}13,120 \\
(17 \%)\end{array}$ & $\begin{array}{l}808,234 \\
(19 \%)\end{array}$ \\
\hline \multicolumn{3}{|l|}{ By Destination } \\
\hline Investment & $\begin{array}{l}30,732 \\
(40 \%)\end{array}$ & $\begin{array}{l}2,467,049 \\
(57 \%)\end{array}$ \\
\hline Working capital & $\begin{array}{l}13,948 \\
(18 \%)\end{array}$ & $\begin{array}{l}995,478 \\
(23 \%)\end{array}$ \\
\hline $\begin{array}{l}\text { Other financial guaran- } \\
\text { tees }\end{array}$ & $\begin{array}{l}1,502 \\
(2 \%)\end{array}$ & $\begin{array}{l}93,467 \\
(2 \%)\end{array}$ \\
\hline $\begin{array}{l}\text { Technical guarantees } \\
\text { (deposits) }\end{array}$ & $\begin{array}{l}28,132 \\
(37 \%)\end{array}$ & $\begin{array}{l}638,100 \\
(15 \%)\end{array}$ \\
\hline $\begin{array}{l}\text { Other technical guar- } \\
\text { antees }\end{array}$ & $\begin{array}{l}2,270 \\
(3 \%)\end{array}$ & $\begin{array}{l}125,452 \\
(3 \%)\end{array}$ \\
\hline \multicolumn{3}{|l|}{ By Maturity } \\
\hline$<1$ year & $\begin{array}{l}2,316 \\
(3 \%)\end{array}$ & $\begin{array}{l}165,956 \\
(4 \%)\end{array}$ \\
\hline $1-3$ years & $\begin{array}{l}7,378 \\
(10 \%)\end{array}$ & $\begin{array}{l}397,563 \\
(9 \%)\end{array}$ \\
\hline $3-5$ years & $\begin{array}{l}9,897 \\
(13 \%)\end{array}$ & $\begin{array}{l}480,354 \\
(11 \%)\end{array}$ \\
\hline $5-8$ years & $\begin{array}{l}11,213 \\
(15 \%)\end{array}$ & $\begin{array}{l}628,444 \\
(15 \%)\end{array}$ \\
\hline$>8$ years & $\begin{array}{l}45,780 \\
(60 \%)\end{array}$ & $\begin{array}{l}2,647,229 \\
(61 \%)\end{array}$ \\
\hline \multicolumn{3}{|l|}{ By SME workers } \\
\hline $1-10$ workers & - & $\begin{array}{l}2,484,847 \\
(58 \%)\end{array}$ \\
\hline $11-25$ workers & - & $\begin{array}{l}725,280 \\
(17 \%)\end{array}$ \\
\hline $26-50$ workers & - & $\begin{array}{l}480,729 \\
(11 \%)\end{array}$ \\
\hline$>50$ workers & - & $\begin{array}{l}628,691 \\
(15 \%)\end{array}$ \\
\hline Total & $\begin{array}{l}76,584 \\
(100 \%)\end{array}$ & $\begin{array}{l}4,319,547 \\
(100 \%)\end{array}$ \\
\hline
\end{tabular}

pandemic that entered into force on April 1, 2020. This new line has extraordinary credit risk coverage to ease the credit flow from banks to SMEs, now counter-guaranteeing $80 \%$ of working capital loans guaranteed by an MGS. ${ }^{20}$ This $80 \%$ counter-guarantee indicates that there was a $60 \%$ increase compared to the situation pre-COVID-19, as working capital operations had been limited to a $50 \%$ counter-guarantee.

The literature $[28,30,31]$ outlines several reasons why governments should prefer guarantee schemes rather than direct lending programs: (i) Credit guarantee systems resemble market-friendly instruments, as the lending decision mostly stays with the private sector. This may confer elements of legitimacy to these schemes that (given the failures of the past) are no longer shared by directed credit and other intervention mechanisms ${ }^{21}$; (ii) the cost of the credit guarantee scheme is usually low, with potential liabilities incurred only in the case of a large institution failure or a systemic crisis $^{22}$; and (iii) relatively small cash outlays can leverage large numbers of loans and volumes of lending.

The public contribution to the guarantee system is characterized by an important leverage effect, resulting in a high number of guarantees formalized (guarantee volume over own funds) ${ }^{23}$ In accordance with current regulations, the minimum capital requirements for credit risk that MGSs must maintain for their granted guarantees are $8 \%$. Therefore, for every euro that public administrations contribute to either the capital or the TPF of the MGS, it may guarantee up to 12.5. ${ }^{24}$ The "best" report of the European Commission [13] states that a reasonable level of leverage for a mature guarantee scheme with a well-diversified portfolio could

$\overline{21}$ Credit risk assessment and loan recovery by the private sector can help improve the quality of risk decisions and minimize loan losses [28]

20 As part of the EU policy response to address the economic disruption caused by COVID-19, there was an increase in the risk-taking capacity of COSME LGF. Certain terms of the instrument were amended to ensure continuous financing support to impacted SMEs, which already received financing under existing counter-guarantee agreements.

22 Appropriate pricing is an important part of a guarantee scheme, both in terms of incentives for lenders and borrowers, as well as for the sustainability of the scheme. Limiting government funding to setup costs might be important in giving the MGSs the proper incentives to monitor borrowers and avoid excessive risk taking, thus minimizing loan losses [28]. It should, however, be noted that some form of public support is inherent in credit guarantee systems in many countries, as income from fees is generally not sufficient to cover both operational costs and loan losses [27]. Honohan [31] concludes that the range of net fiscal cost may vary substantially between zero and at least $15 \%$ per annum of outstanding guarantees.

23 As not all borrowers will default, the total amount of guaranteed credits is larger than the capitalization of the scheme. More precisely, the leverage tells how much credit has been generated toward SMEs by a given amount of capital endowment of the fund [27].

${ }^{24}$ This multiplier effect is amplified if we take into account the existence of a counter-guarantee system (as regulatory capital requirements will be reduced). However, additional capital requirements demanded by investors and more risky businesses in a portfolio mean a lower leverage. 
Table 4 Activity of the five most important MGSs in Spain in 2019. Source: Own elaboration

\begin{tabular}{lllll}
\hline Name & Region of activity & $\begin{array}{l}\text { Outstanding } \\
\text { risk*** } \\
\text { (in thousands of } \\
\text { euros) }\end{array}$ & $\begin{array}{l}\text { Formalized guar- } \\
\text { antees } \\
\text { (in thousands of } \\
\text { euros) }\end{array}$ & $\begin{array}{l}\text { Number of participat- } \\
\text { ing partners (SMEs) }\end{array}$ \\
\hline Avalis & Catalonia & 392,846 & 147,207 & 4,515 \\
Avalmadrid & Madrid & 310,595 & 76,292 & 10,950 \\
Elkargi* & Basque Country & 888,085 & 300,867 & 15,571 \\
Garántia & Andalusia & 438,681 & 141,781 & 16,707 \\
Iberaval** & Castile and Leon & 849,325 & 318,775 & 28,660 \\
\hline
\end{tabular}

*Although Elkargi focuses its activity mainly in the Basque country, it also operates in Navarra. **Although Iberaval focuses its activity mainly in Castile and Leon, it also operates in La Rioja and Madrid. $* * *$ as of $12 / 31 / 2019$

Table 5 COVID-19 financing lines launched by the main Spanish MGSs in 2020. Source: Own elaboration

\begin{tabular}{|c|c|c|c|}
\hline Regional Government & MGS & Regulation & Objective \\
\hline Andalusia & Garántia & $\begin{array}{l}\text { Decree-Law 3/2020 } \\
\text { Decree-Law } 11 / 2020\end{array}$ & $\begin{array}{l}\text { Guarantee SME working capital operations for an } \\
\text { amount of up to } 500 \text { million euros; an additional } \\
100 \text { million euros guarantee financing for micro- } \\
\text { credits with better conditions. It also establishes } \\
\text { a subsidy for part of the cost of the guaranteed } \\
\text { operations }\end{array}$ \\
\hline Basque Country & Elkargi & $\begin{array}{l}\text { Decree-Law 50/2020 } \\
\text { Decree-Law 67/2020 }\end{array}$ & $\begin{array}{l}\text { Guarantee SME working capital operations for an } \\
\text { amount of up to } 1,000 \text { million euros }\end{array}$ \\
\hline Castile and Leon & Iberaval & $\begin{array}{l}\text { Government Agreements }(04 / 02 / 2020 ; 6 / 11 / 2020 \text {; } \\
\text { 11/19/2020; 12/03/2020; 12/17/2020) }\end{array}$ & $\begin{array}{l}\text { Guarantee SME working capital and investment } \\
\text { operations in some industries for an amount of up } \\
\text { to } 272 \text { million euros. Partial subsidy for financial } \\
\text { costs }\end{array}$ \\
\hline Catalonia & Avalis & $\begin{array}{l}\text { Decree-Law 6/2020 } \\
\text { Decree-Law 8/2020 }\end{array}$ & $\begin{array}{l}\text { Guarantee working capital operations for an amount } \\
\text { of up to } 300 \text { million euros. Special line for self- } \\
\text { employed workers and microbusinesses in the } \\
\text { restaurant and commercial sectors }\end{array}$ \\
\hline Madrid & Avalmadrid & Government Agreements (04/17/2020; 05/06/2020) & $\begin{array}{l}\text { Guarantee SME financing operations and subsidize } \\
\text { the financial costs of the operations through a } 20 \\
\text { million euro contribution }\end{array}$ \\
\hline
\end{tabular}

reach 6 to 7 times. Moreover, as long as guaranteed loans are being repaid, the same funds will cover the risks of new formalized operations without the need to make additional public contributions.

Table 5 summarizes some of the programs launched in 2020 by the main Spanish MGSs in collaboration with the respective regional public administration to cope with the economic impact of the coronavirus. ${ }^{25}$

The regional government of Andalusia's Decree-Law 3/2020 of March 16th, which relates to measures of financial and tax support for the economic sector and measures of social emergency to protect Andalusian SME financing from the impact of COVID-19, granted to Garántia (the regional

\footnotetext{
25 As the liquidity crisis caused by the coronavirus continues, many of these programs have been extended, and new help credit lines have even been launched.
}

MGS) an amount of up to 36 million euros to strengthen its solvency. This contribution to the TPF would enable the company to guarantee working capital operations for SMEs for a total amount of up to 500 million euros. Likewise, in May, Decree-Law 11/2020 established a new line of guarantees for microcredits (from 9000 to 15,000 euros) with better conditions for self-employed people. It also established the possibility of a 1-year grace period as well as the subsidization of part of the financial costs of the guaranteed loans (the coverage of the guarantee cost, the opening fees, and the interest of the loan during the grace period) in the two lines of financing.

In the same vein, the Basque Government approved Decree-Laws 50/2020 and 67/2020 to support financial programs and respond to the economic impact of COVID-19 on SMEs. This financing line, with a 1000 million euros capacity, tried to satisfy the 6-month working capital financing needs of SMEs affected by COVID-19 through collaboration 
Table 6 Activity of the five most important MGSs in Spain in 2020. Source: Own elaboration

\begin{tabular}{llll}
\hline Name & $\begin{array}{l}\text { Outstanding risk* (in thou- } \\
\text { sands of euros) }\end{array}$ & $\begin{array}{l}\text { Formalized guarantees (in } \\
\text { thousands of euros) }\end{array}$ & $\begin{array}{l}\text { Number of par- } \\
\text { ticipating partners } \\
\text { (SMEs) }\end{array}$ \\
\hline Avalis & 521,774 & 268,387 & 5,582 \\
Avalmadrid & $(32.8 \%)$ & $(82.3 \%)$ & $(23.6 \%)$ \\
Elkargi & 320,561 & 112,662 & 11,296 \\
& $(3.2 \%)$ & $(47.7 \%)$ & $(3.2 \%)$ \\
Garántia & $1,586,201$ & 948,198 & 21,693 \\
& $(78.6 \%)$ & $(215.2 \%)$ & $(39.3 \%)$ \\
Iberaval & 561,516 & 218,540 & 20,593 \\
& $(28.0 \%)$ & $(54.1 \%)$ & $(23.3 \%)$ \\
& 990,925 & 390,376 & 31,135 \\
\end{tabular}

The percentage increase from 2019 to 2020 is reported in parentheses. *as of 12/31/2020 agreements with banks for operations guaranteed by the regional MGS, Elkargi. SME loans granted under this line have better conditions than those on the market, with part of the costs of the guarantee subsidized. The regulation also provides an additional counter-guarantee for those financing operations guaranteed by Elkargi.

The regional government of Castile and Leon contributed a total of 28.8 million euros to Iberaval during 2020 to provide liquidity to entrepreneurs and SMEs affected by COVID-19. This amount includes both contributions to the TPF and a reduction to the financial costs of the guaranteed loans (guarantee costs, bank commissions, and interest). These contributions are expected to mobilize up to 272 million euros in SME loans under very advantageous conditions.

The Government of Catalonia approved Decree-Laws 6/2020 and 8/2020 to mitigate the effects of COVID-19 on SMEs. By signing a collaboration agreement with Avalis (the Catalonian MGS), a contribution to the TPF of 30 million euros was established to guarantee working capital operations for an amount of up to 300 million euros. In addition, a financing line of up to 20 million euros under special advantageous conditions was established to help selfemployed workers and microbusinesses in the restaurant and commercial sectors.

Finally, in the case of Madrid, through the Government Agreement of April 17, the regional government contributed 12 million euros to the TPF of Avalmadrid (the local MGS). Through the Government Agreement of May 6, the regional government also subsidized payments of commissions, interest, and amortization expenses associated with the subscribed operations, as well as commissions associated with the guarantees provided (a maximum of $6.5 \%$ of the principal amount).

In summary, most regional governments have established liquidity credit lines for SMEs based on contributions to the TPF of the local MGS that they participate in. Additionally, most of these programs include some grace period as well as a partial subsidy of the costs of the loan and/or guarantee for the beneficiary SME. ${ }^{26}$ As might be expected, the companies' activity increased considerably during 2020 (see Table 6).

\section{Concluding remarks}

Credit guarantee schemes have become an important instrument of choice for policymakers to increase access to lending, especially for constrained groups such as small businesses [28]. The establishment of a credit guarantee scheme reduces informational asymmetries between firms and banks, increasing the availability of funds for viable projects and providing financing at a lower cost and a longer term ([28, 39, 40], among others). ${ }^{27}$ MGS activity has become even more important as a consequence of the liquidity shortfalls experienced by SMEs during the coronavirus pandemic. ${ }^{28}$

The role of the public sector is crucial in the development and consolidation of mutual guarantee systems because it is able to act in three complementary ways: (i) by establishing a reinsurance structure (i.e., counter-guarantees) as an element to reduce the global risk of the MGS, (ii) by partially subsidizing the costs of the loan and/or guarantee for the beneficiary SME, and (iii) by making a contribution to the

\footnotetext{
${ }^{26}$ The rationale for this subsidy is that the additional cost of the guarantee for the SME may limit the reach of the system, although in many cases the fee is compensated, at least in part, by a reduction in the interest rate applied by the bank [27].

27 Informational asymmetries between small firms and banks may be so pronounced that even profitable investment opportunities could be not financed [41, 42].

${ }^{28}$ See [1] for an excellent discussion about how SMEs have been affected by the COVID-19 pandemic.
} 
capital and/or the TPF of the society. ${ }^{29}$ In Spain, the central government usually supports the activity of MGSs through the first option (i.e., establishing a counter-guarantee system maintained by the public company CERSA), while regional administrations mainly use cost subsidies and contributions to the capital and/or the TPF.

This paper shows that the use of guarantee schemes to improve SMEs' access to financing may limit the burden on the public budget. The "multiplier effect" of public contributions to MGSs makes this instrument very cost-effective, allowing it to be applied to a larger population of SMEs with the same amount of support funds, coinciding with recent recommendations from G30 for the post-COVID-19 era. ${ }^{30}$ The greater access to financing for SMEs facilitated by the guarantee system, especially in crises as serious as that caused by the coronavirus pandemic, has an important effect on overall economic welfare in terms of maintaining employment and safeguarding the survival of the companies themselves. $^{31}$

Acknowledgements We are grateful to the two anonymous referees and the Editor for their useful comments and suggestions. We also acknowledge the financial support of the Regional Government of Andalusia, Spain (Research Group SEJ-555). The usual disclaimer applies.

\section{Compliance with ethical standards}

Conflict of interest Félix Corredera-Catalán and Filippo Di Pietro declare that they have no conflicts of interest. Antonio Trujillo-Ponce is a member of the board of directors of a mutual guarantee society. The views expressed here are the sole responsibility of the authors and do not necessarily reflect the views of the society.

\section{References}

1. Organisation for Economic Co-operation and Development (OECD). 2020. Coronavirus (COVID-19): SME policy responses. OECD Policy Responses to Coronavirus (COVID-19). https://

\footnotetext{
${ }^{29}$ Governments also support MGSs by granting tax reductions and exemptions.

${ }^{30} \mathrm{G} 30$ recommends policy makers take advantage of private sector capacities where they exist, in order to leverage scarce public resources and to make use of private sector expertise to evaluate the viability of businesses [43]. This report also recommends governments focus on those firms that need support but are expected to be viable, with a special emphasis on SMEs.

31 The effect of increased access to finance on overall economic welfare is also referred to as economic additionality. This effect is measured in terms of changes in the sales, employment, investment and innovation performance of the small businesses supported, or, at the macro-level, by its influence on competitiveness and economic growth. Measuring economic additionality has proven to be particularly challenging [27].
}

www.oecd.org/coronavirus/policy-responses/coronavirus-covid -19-sme-policy-responses-04440101. Accessed 24 October 2020.

2. Chen, S, Igan, D., Pierri, N., Presbitero, A. 2020. Tracking the economic impact of COVID-19 and mitigation policies in Europe and the United States. Special Series on COVID-19. International Monetary Fund. https://www.imf.org/en/Publications/WP/Issue s/2020/07/10/Tracking-the-Economic-Impact-of-COVID-19-andMitigation-Policies-in-Europe-and-the-United-49553. Accessed 18 October 2020.

3. Chen, S, Igan, D., Pierri, N., Presbitero, A. 2020. The economic impact of COVID-19 in Europe and the US. VOX, CEPR Policy Portal. https://voxeu.org/article/economic-impact-covid-19-europ e-and-us. Accessed 18 October 2020.

4. Liu, H. and Volker, D. 2020. Where have the paycheck protection loans gone so far? Liberty Street Economics. https://libertystreetec onomics.newyorkfed.org/2020/05/where-have-the-paycheck-prote ction-loans-gone-so-far.html. Accessed 24 October 2020.

5. Gobbi, G., Palazzo, F., Segura, A. 2020. Unintended effects of loan guarantees. VOX, CEPR Policy Portal. https://voxeu.org/artic le/unintended-effects-loan-guarantees. Accessed 24 October 2020.

6. European Commission. 2019. Annual report on European SMEs 2018/2019. Research \& development and innovation by SMEs. Background Document. November.

7. Blanchflower, D.G., and A.J. Oswald. 1998. What Makes an Entrepreneur? Journal of Labor Economics 16 (1): 26-60.

8. Dunn, T., and D. Holtz-Eakin. 2000. Financial Capital, Human Capital, and the Transition to Self-Employment: Evidence form Intergenerational Links. Journal of Labor Economics 18 (2): 282-305.

9. De Cleyn, S.H., and J. Braet. 2012. Do Board Composition and Investor Type Influence Innovativeness in SMEs? International Entrepreneurship and Management Journal 8 (3): 285-308.

10. Mahagaonkar, P. 2010. Money and ideas. Four studies on finance, innovation and the business life cycle. Springer.

11. Cowling, M., W. Liu, and A. Ledger. 2012. Small Business Financing in the UK Before and During the Current Financial Crisis. International Small Business Journal 30 (7): 778-800.

12. European Central Bank. 2018. Survey on the access to finance of enterprises in the euro area-April to September 2018. https:// www.ecb.europa.eu/stats/accesstofinancesofenterprises/html/ecb. safe201811.en.html. Accessed 15 September 2020.

13. European Commission. 2006. Guarantees and mutual guarantees. Best Reports, No. 3.

14. Akerlof, G. 1970. The Market for Lemons: Qualitative Uncertainty and the Market Mechanism. Quaterly Journal of Economics 84 (3): 488-500.

15. Greenbaum, S.I., and A.V. Thakor. 1995. Contemporary financial intermediation. N.Y.: The Dryden Press.

16. De Meza, D., and C. Southey. 1996. The Borrower's Curse: Optimism, Finance and Entrepreneurship. Economic Journal 106 (435): 375-386.

17. Camerer, C.F., and D. Lovallo. 1999. Overconfidence and Excess Entry: An Experimental Approach. American Economic Review 89 (1): 306-318.

18. Arenius, P., and M. Minniti. 2005. Perceptual Variables and Nascent Entrepreneurship. Small Business Economics 24: 233-247.

19. Elyasiani, E., and L. Goldberg. 2004. Relationship Lending: A Survey of the Literature. Journal of Economics and Business 56: 315-330.

20. Angelini, P., R. Di Salvo, and G. Ferri. 1998. Availability and Cost of Credit for Small Businesses: Customer Relationships and Credit Cooperatives. Journal of Banking \& Finance 22 (6-8): 925-954.

21. Baas, T., and M. Schrooten. 2006. Relationship Banking and SMEs: A Theoretical Analysis. Small Business Economics 27: 127-137. 
22. Berglöf, R. 1990. Capital structure as a mechanism of control: A comparison of financial systems. In The Firm as a nexus of treaties, ed. M. Aoki, et al. London: Sage Publications.

23. Casasola, M.J., and C. Cardone. 2009. Too Important to Fail: ¿Favorecen las Relaciones Bancarias la Situación Crediticia de las PYMES Españolas? Universia Business Review 24: 12-29.

24. Ono, A., and I. Uesugi. 2009. Role of Collateral and Personal Guarantees in Relationship Lending: Evidence from Japan's SME Loan Market. Journal of Money, Credit and Banking 41 (5): 935-960.

25. CESGAR. 2020. Informe anual 2019. http://www.cesgar.es/wpcontent/uploads/2020/06/INFORME_CESGAR_2019_web_ compressed.pdf. Accessed 01 September 2020.

26. Bester, H. 1987. The Role of Collateral in Credit Markets with Imperfect Information. European Economic Review 31 (4): 887-899.

27. Cusmano, L. 2018. SME and entrepreneurship financing: The role of credit guarantee schemes and mutual guarantee societies in supporting finance for small and medium-sized enterprises. OECD SME and Entrepreneurship Papers, No. 1, OECD Publishing, Paris. https://doi.org/10.1787/35b8fece-en.

28. Beck, T., L. Klapper, and J. Mendoza. 2010. The Typology of Partial Credit Guarantee Funds Around the World. Journal of Financial Stability 6 (1): 10-25.

29. Beck, T., A. Demirgüç-Kunt, and M.S. Martínez Pería. 2008. Banking SMEs around the world: Drivers, obstacles, business models and lending practices. Mimeo: World Bank.

30. Arping, S., G.L. Lóránth, and A.D. Morrison. 2010. Public Initiatives to Support Entrepreneurs: Credit Guarantees Versus Cofunding. Journal of Financial Stability 6 (1): 26-35.

31. Honohan, P. 2010. Partial Credit Guarantees: Principles and Practice. Journal of Financial Stability 6 (1): 1-9.

32. Stiglitz, J., and A. Weiss. 1981. Credit Rationing in Markets with Imperfect Information. American Economic Review 71: 393-410.

33. Organisation for Economic Co-operation and Development (OECD). 2006. The SME financing gap. Theory and evidence. Volume I. Paris.

34. Berger, A.N., and G.F. Udell. 1990. Collateral, Loan Quality and Bank Risk. Journal of Monetary Economics 25 (1): 21-42.

35. European Commission. 2020. Access to finance for SMEs: Policy areas. Brussels: DG Internal Market, Industry, Entrepreneurship and SMEs. https://ec.europa.eu/growth/access-to-finance/fundi ng-policies_en. Accessed 10 September 2020.

36. Pombo, P., H. Molina, and J.S. Ramírez. 2007. Propuesta Para una Clasificación y Terminología Internacional de los Sistemas/ Esquemas de Garantía: Conceptos, Características y Definiciones. Revista Facultad de Ciencias Económicas: Investigación y Reflexión XV (1): 53-76.

37. Cardone-Riportella, C., and M. García-Mandaloniz. 2017. Does Recent Regulation Improve (or Not) the Spanish Mutual Guarantee System? International Journal of Economics and Financial Issues 7 (1): 515-523.

38. Cardone-Riportella, C., A. Trujillo-Ponce, and A. Briozzo. 2013. Analyzing the Role of Mutual Guarantee Societies on Bank
Capital Requirements for Small and Medium-Sized Enterprises. Journal of Economic Policy Reform 16 (2): 142-159.

39. Columba, F., L. Gambacorta, and P.E. Mistrulli. 2010. Mutual Guarantee Institutions and Small Business Finance. Journal of Financial Stability 6 (1): 45-54.

40. D'Ignazio, A., and C. Menon. 2020. Causal Effect of Credit Guarantees for Small- and Medium-Sized Enterprises: Evidence from Italy. Scandinavian Journal of Economics 122: 191-218.

41. Petersen, M.A., and R.G. Rajan. 1994. The Benefit of Firm-Creditor Relationships: Evidence from Small Business Data. Journal of Finance 1: 3-37.

42. Berger, A.N., and G.F. Udell. 2006. A More Complete Conceptual Framework for SME Finance. Journal of Banking and Finance 30 (11): 2945-2966.

43. G30 Working Group on Corporate Sector Revitalization. 2020. Reviving and restructuring the corporate sector post-covid: Designing public policy interventions. Washington, D.C.

Publisher's Note Springer Nature remains neutral with regard to jurisdictional claims in published maps and institutional affiliations.

Félix Corredera-Catalán is a Ph.D. student in economics and business at the University of Seville (Spain). His research interests are focused on finance, with a particular emphasis on working capital and SMEs. $\mathrm{He}$ is also enrolled in a Corporate Masters in Business Administration (CMBA) program at Esade. Since 2018, he has been the chief financial officer (CFO) at a software and consulting company. Previously, he held several positions, such as treasurer and supply chain manager, in the finance department of a Spanish multinational company for 9 years

Filippo di Pietro Ph.D., is a senior lecturer in finance at the Universidad de Sevilla (Spain). He worked as an economist at the Joint Research Center (European Commission). He has been a visiting professor at different European universities. His current research interests include spatial financial economics, regional financial systems, corporate finance, SMEs, innovation, and growth. His recent contributions have been published in Spatial Economic Analysis, Long Range Planning, the Journal of Financial Services Research, Small Business Economics, Regional Studies, and the Journal of International Financial Management \& Accounting

Antonio Trujillo-Ponce is a senior lecturer in finance at the Pablo de Olavide University of Seville (Spain). He is currently the director of the Banking and Entrepreneurial Finance Research Group (BANEF). His research interests are focused on banking and finance, with a particular emphasis on bank regulation. He has published over 20 academic research articles in various journals, such as the Journal of Banking and Finance, the Journal of Financial Services Research, the Journal of Business Ethics, Accounting and Finance, and the Journal of Economic Policy Reform 